УДК 341.23:[351.746:007]

DOI https://doi.org/10.32837/pyuv.v0i1(30).552

\author{
П.О.Яковлев \\ orcid.org/0000-0003-0172-5946 \\ кандидат юридичних наук, \\ докторант кафедри державно-правових дисииплін \\ Харківського національного університету імені В. Н. Каразіна
}

\title{
УНІВЕРСАЛЬНІ МІЖНАРОДНО-ПРАВОВІ СТАНДАРТИ ДЕРЖАВНОГО УПРАВЛІННЯ У СФЕРІ ЗАБЕЗПЕЧЕННЯ ІНФОРМАЦІЙНОЇ БЕЗПЕКИ
}

Обгрунтування актуальності обраної тематики. Основне призначення сучасного міжнародного права полягає у виробленні та консенсуальному схваленні універсальних для всіх держав світу модальностей державної політики з питань забезпечення прав і свобод людини, а також міжнародного миру, безпеки та міжнародного правопорядку. Задля збереження фундаментальних загальних цивілізаційних цінностей, як на універсальному рівні Організації Об'єднаних Націй (далі - $\mathrm{OOH}$ ), так і на рівні регіонального співробітництва держав, прогресивна світова спільнота постійно працює над координацією зусиль держав щодо розв'язання глобальних і регіональних проблем, а також попередження формування можливих загроз внутрішньодержавному і міжнародному розвитку. Однією з таких проблем $€$ посягання на інформаційну безпеку суверенної держави, коли національний інформаційний простір стає об'єктом недоброзичливих посягань ыз боку інших держав або контрольованих ними суб'єктів. За таких умов держави на національному рівні вживають заходи державного управління у сфері забезпечення інформаційної безпеки. 3 урахуванням того, що міжнародне право намагається пристосуватися до постійного прискорення розвитку соціуму та інформаційних технологій, поступово на рівні актів ООН сформувалися універсальні засади розробки, планування і реалізації внутрішньої державної політики у сфері забезпечення інформаційної безпеки. Відповідно, актуальним завданням правової доктрини $є$ їх всебічне дослідження та вироблення рекомендацій щодо адаптації на внутрішньодержавному рівні. Тому метою статті є висвітлення міжнародно-правових стандартів державного управління у сфері забезпечення інформаційної безпеки на національному рівні.

Обрані у спектр наукової уваги питання частково досліджувалися такими вченими, як О.В. Бойченко, С.М. Заброда, Н.В. Коршунова, О.М. Кісілевич-Чорнойван, О.М. Фролова та ін. Проте доктринальна розробка аспектів універсальних міжнародно-правових стандартів здійснення державного управління у сфері інформаційної безпеки на національному рівні потребує поглиблення з урахуванням актуалізації проблематики використанняінформаціїякресурсудержавногорозвитку.
Виклад основного матеріалу. Варто зазначити, що акти міжнародного права містять значну кількість правових конструкцій, які тим чи іншим чином регламентують аспекти реалізації державної політики з питань забезпечення інформаційної безпеки. Значною мірою їх змістовне наповнення зумовлено тим, що станом на кінець ХХ ст. міжнародна спільнота остаточно переконалася в тому, що інформаційна безпека окремих держав у міжнародному інформаційному просторі є складником міжнародної інформаційної безпеки [1]. Ми розкриємо зміст лише тих положень, які є найбільш універсальними і набули значення стандарту, тобто стали типовими для здійснення заходів забезпечення інформаційної безпеки.

Міжнародно-правові стандарти здійснення державної політики в будь-якій сфері передбачають дотримання принципів і норм, що закріплюють обов'язкові або модальні правила поведінки держави в різних галузях та виражають прагнення міжнародного співтовариства максимально скоординувати політику, засоби й методи діяльності та безпосередньо діяльність [2, с. 361]. Міжнародні стандарти формалізуються в джерелах міжнародного та міждержавного права, якими $\epsilon$ установчі договори міжнародних організацій, декларації, конвенції, пакти, положення, угоди таін.

Універсальні міжнародно-правові стандарти державного управління у сфері забезпечення інформаційної безпеки є похідними від загальних принципів функціонування апарату управління, які визнано ООН як загальні (пріоритет дотримання прав людини, демократизм політичної системи, верховенство закону і т.д.). С.М. Заборода в цьому контексті вказує на тре, що міжнародно-правові стандарти здійснення внутрішньої політики держави містять спільно розроблені державами підходи й міжнародно-легальні принципи становлення, формування та функціонування певних публічних і приватних інститутів на території конкретних держав [3]. Ще в часи перебування України у складі СРСР та після 1991 р. наша держава приєдналася до основних міжнародних документів $\mathrm{OOH}$ у галузі прав людини, які визначають базові засади діяльності суб'єктів державної політики у сферах забезпечення прав і свобод людини, 
національної безпеки й оборони, розвитку інститутів громадянського суспільства, обороту інформації тощо. Невипадково Стратегія національної безпеки України від 26.05.2015 р. визначає, що політика національної безпеки України грунтується на повазі до норм і принципів міжнародного права [4]. 3 огляду на це, виокремлення основних міжнародно-правових стандартів державного управління у сфері забезпечення інформаційної безпеки держави передбачає аналіз положень окремих актів міжнародного права, які містять керівні приписи для розробки і реалізації на національному рівні політики у визначеній сфері.

Попередньо зазначимо, що на рівні ООН питання щодо вироблення стандартів внутрішньої державної політики у сфері забезпечення інформаційної безпеки набуло актуальності лише в останні десятиліття. Починаючи з середини 1990-х рр. основна увага міжнародної спільноти була прикута до формування універсальної міжнародно-правової основи протидії загрозам у міжнародній інформаційній сфері. Зазначені аспекти детально висвітлені в науковому доробку О.М. Флорової, яка вказує на те, що увага міжнародної спільноти в останню чверть століття прикута здебільшого до розробки міжнародно-правових основ протидії транснаціональним інформаційним загрозам [5]. Разом із тим Статут Організації Об'єднаних Націй від 26.06.1945 р. містить низку засадничих принципів формування внутрішньої політики держави, які є обов'язковими у всіх сферах соціального управління, в тому числі інформаційній. Зокрема, згідно зі ст.ст. 1, 2 держави зобов'язуються розробляти і вживати заходи державної політики, які передбачають сприяння подолання загроз миру і безпеці, придушення актів агресії, недопущення посягання на політичній устрій або недоторканість кордонів держав, унеможливлення втручання у внутрішні справи держави [6]. Зазначені стандарти мають фундаментальне значення для здійснення управлінських заходів у сфері забезпечення національних інтересів кожної сучасної суверенної держави в інформаційній сфері.

Загальна декларація прав людини від 10.12.1948 р. у ст. 19 містить універсальний постулат, що кожна людина має право вільно шукати, одержувати і поширювати інформацію та ідеї будь-якими засобами і незалежно від державних кордонів [7]. Зазначена норма є одним із засадничих стандартів функціонування правових систем абсолютної більшості демократичних країн світу і є орієнтиром для здійснення державного управління. Не можна обійти увагою і положення Міжнародного пакту про громадянські і політичні права від 16.12.1966 р., який також містить приписи про основні права особи в інформаційні сфері [8]. Зокрема, в документі сформульовано, що кожна особа має право на вільне висловлення власної думки, що включає право вільно шукати, одержувати і поширювати інформацію. Вказане положення частково дублює норму Загальної декларації прав людини. Відповідно, заходи державної політики у сфері забезпечення інформаційної безпеки і захисту національних інтересів в інформаційній сфері суверенної держави мають враховувати зазначені загальноцивілізаційні постулати. Протидія загрозам національному інформаційному середовищу шляхом використання примусових адміністративно-юрисдикційних i кримінально-юрисдикційних заходів завжди має передбачати правові механізми повноцінного забезпечення права особи на вільний пошук і збір інформації, а у разі порушення такого права можливість використання правових механізмів компенсації завданої шкоди.

У додаток до наведеного варто також вказати на положення деяких Конвенцій Ради Європи і $\mathrm{OOH}$, які регулюють окремі аспекти організації державної політики у сфері забезпечення інформаційної безпеки. Зокрема, привертають увагу деякі положення Конвенції Ради Європи про кіберзлочинність, яку було ратифіковано також Україною законом від 07.09.2005 р. № 2824-IV [9]. Так, документ закріплює систему важливих положень, які імперативно мають враховувати суверенні держави як стандарти розробки і реалізації заходів управлінської політики, спрямованої на забезпечення інформаційної безпеки. Зокрема, це баланс між правоохоронними інтересами і повагою до основних прав людини, підвищення ефективності кримінальних розслідувань і переслідувань, що стосуються кримінальних правопорушень, пов'язаних із комп'ютерними системами, криміналізація діянь, що пов'язані з посяганням на кіберпростір. Окрім цього, Конвенція ООН про використання електронних повідомлень у міжнародних договорах, яка затверджена резолюцією ГА ООН 60/21 від 23.11.2005 р., закріплює, що держава сприяє визнанню юридичної сили інформації, яка міститься в електронних повідомленнях, що використовуються у процесі налагодження міжнародної торгівлі [10]. Таким чином, держава сприяє стимулюванню комерційної діяльності, а також активізації міжнародної торгівлі.

$\mathrm{He}$ менш важливе значення для формування міжнародно-правових стандартів державного управління у сфері забезпечення інформаційної безпеки мають Резолюції Генеральної Асамблеї $\mathrm{OOH}$ (далі - ГА ООН). Їх особливістю $\epsilon$ те, що вказаний вид документів приймається за результатами предметних обговорень їх змісту у середовищі спеціалістів, у процесі роботи міждержавних конференцій, переговорів лідер держав світу тощо. Такий принцип, як справедливо наголошує О.В. Бойченко, дає змогу прийняти «виважений” міжнародний нормативно-правовий акт 3 урахуванням специфіки національних законодавств [11, с. 79$]$. За два останніх десятиліття 
ГА ООН схвалила значну кількість резолюцій, які торкаються питань забезпечення інформаційної безпеки держави на національному рівні. Ми виокремимо, на наш погляд, кілька найважливіших. Перший документ - Резолюція ГА ООН $60 / 45$ «Досягнення у галузі інформатизації та телекомунікацій в контексті міжнародної безпеки" в редакції від 02.12.2008 р. [12]. Резолюція закріплює положення про те, що держави-члени $\mathrm{OOH}$ розробляють управлінські заходи, спрямовані на протидію загрозам інформаційної безпеки з урахуванням гарантування дотримання вільного доступу до інформації. Наступний стандарт сформульовано у Резолюції ГА ООН 64/211 «Створення глобальної культури кібербезпеки та оцінка національних зусиль із захисту найважливіших інформаційних інфраструктур» від 21.12.2009 р. [13]. Зокрема, в документі визначено, що кожна держава самостійно визначає заходи захисту власних інформаційних інфраструктур за умови забезпечення рівного доступу до інформаційних технологій та обміну інформацією з міжнародним співтовариством із питань актуальних загроз інформаційному середовищу. Окрім цього, акцентуємо на тому, що важливими міжнародно-правовими стандартами державного управління у сфері забезпечення інформаційної безпеки є забезпечення гендерної рівності в доступі і використанні інформаційних технологій, гарантування державою змоги недостатньо соціально забезпечених верств населення користуватися інформаційними технологіями, налагодження державно-приватного партнерства у фінансуванні розвитку інформаційно-комунікаційної інфраструктури. Ці стандарти зафіксовано у Резолюції ГА ООН 65/141 «Використання інформаційно-комунікаційних технологій 3 метою розвитку» від 20.12.2010 р. [14]. Зміст наведених положень резолюцій підтверджує, що ООН враховує глобальні проблеми сучасності у процесі формування універсальних пропозицій із питань протидії загрозам інформаційної безпеки на національному рівні.

Висновки та пропозиції. Враховуючи наведене вище, сучасне міжнародне право на універсальному рівні закріплює значну кількість положень, які є стандартами розробки і реалізації заходів державного управління у сфері забезпечення інформаційної безпеки на національному рівні суверенними державами. Такі стандарти закріплюються у Статуті ООН, найважливіших документах $\mathrm{OOH}$ у галузі прав людини, Конвенціях ОOH, Peзолюціях ООН. Аналіз регуляторного змісту стандартів доводить, що їх зміст відповідає загальноцивілізаційним засадам забезпечення права особи на інформацію, інтересам миру, регіональної і світової стабільності, недопущення геополітичних і внутрішньодержавних конфліктів. Крім цього, передбачається, що практичне втілення відповідних положень стане потужним чинником збіль- шення рівня доступності інформаційно-комунікаційних технологій для всіх верств населення держав світу, буде сприяти розвитку інформаційно-комунікаційної інфраструктури суверенних держав, дасть додатковий імпульс для законодавчої регламентації забезпечення інформаційної безпеки на національному рівні. Разом із тим міжнародно-правова основа здійснення державного управління у сфері забезпечення інформаційної безпеки потребує вдосконалення в частині розробки і затвердженні окремого акта міжнародного права, який би містив уніфікований перелік рекомендованих стандартів для суверенних держав, що втілювалися б задля забезпечення інформаційної безпеки на національному рівні. Означені питання мають стати пріоритетним напрямом подальших наукових розробок.

\section{Jimepamypa}

1. Кісілевич-Чорнойван О.М. Інформаційна безпека та міжнародна інформаційна безпека: проблема визначення понять. Інтернет-сайт «Правник. Бібліотека наукової юридичної літератури». URL: http://www.pravnuk.info/2013-12-27-15-12-23/ 120-informacijna-bezpeka-ta-mizhnarodna-informacijnabezpeka-problema-viznachennya-1ponyat.html (дата звернення: 14.04.2020)

2. Коршунова Н.В. Міжнародні та європейські стандарти державної політики. Юридичний часопис Національної академії внутрішніх справ. 2017. № 1 (13). C. $360-370$

3. Заброда С.М. Міжнародно-правові стандарти поліцейської діяльності щодо протидії насильству в сім'ї. Право і суспільство. 2012. № 2. С. 161-168. URL: http://nbuv.gov.ua/UJRN/Pis_2012_2_389 (дата звернення: 10.04.2020)

4. Про рішення Ради національної безпеки і оборони України від 6 травня 2015 р. «Про Стратегію національної безпеки України»: Указ Президента від 26.05 .2015 р. № 287/2015. Офіиійний вісник Президента України. 2015. № 13. Ст. 874.

5. Фролова О.М. Роль ООН в системі міжнародної інформаційної безпеки. Міжнародні відносини. Серія «Політичні науки». 2018. № 18-19. URL: http://journals.iir.kiev.ua/index.php/pol_n/article/ view/3468 (дата звернення: 20.04.2020)

6. Устав Организации Объединённых Наций и Устав Международного Суда. Офіиійний інтернет-сайт Верховної Ради України. URL: https://zakon.rada.gov.ua/ laws/show/995_010 (дата звернення: 19.04.2020)

7. Загальна декларація прав людини. Прийнята і проголошена резолюцією 217 А (III) Генеральної Асамблеї ООН від 10 грудня 1948 р. Офіційний інтернет-сайт Верховної Ради України. URL: https://zakon.rada.gov.ua/laws/show/995_015 (дата звернення: 15.04.2020)

8. Международный пакт о гражданских и политических правах. URL: https://www.un.org/ru/documents/ decl_conv/conventions/pactpol.shtml (дата звернення: 14.04.2020)

9. Про ратифікацію Конвенції про кіберзлочинність : Закон України від 07.09.2005 p. № 2824-IV. Biдомості Верховної Ради України. 2006. № 5. Ст. 71.

10. Конвенція $\mathrm{OOH}$ про використання електронних повідомлень у міжнародних договорах. 
URL: https://www.un.org/ru/documents/decl conv/ conventions/elect_com.shtml(дата звернення: 20.04.2020)

11. Бойченко О.В. Міжнародна інформаційна безпека: проблеми і перспективи. Форум права. 2009. № 3. C. 74-79. URL: http://nbuv.gov.ua/UJRN/FP index. htm 2009313 (дата звернення: 20.04.2020).

12. Резолюція $60 / 45$, прийнята Генеральною Асамблеєю Організації Об'єднаних Націй «Досягнення у галузі інформатизації та телекомунікацій в контексті міжнародноїбезпеки».URL:https://zakon.rada.gov.ua/ laws/show/995_e45/card2\#Card (дата звернення: 15.04.2020).

13. Резолюція 64/211, прийнята Генеральною Асамблеєю Організації Об'єднаних Націй «Створення глобальної культури кібербезпеки та оцінка національних зусиль із захисту найважливіших інформаційних інфраструктур». URL: https://undocs.org/ru/A/ RES/64/211 (дата звернення: 16.04.2020).

14. Резолюції 65/141, прийнята Генеральною Асамблеєю Організації Об'єднаних Націй «Використанні інформаційно-комунікаційних технологій 3 метою розвитку». URL: https://undocs.org/ru/A/ $\mathrm{RES} / 65 / 141$ (дата звернення: 08.04.2020).

\section{Анотація}

Яковлєв П. О. Універсальні міжнародно-правові стандарти державного управління у сфері забезпечення інформаційної безпеки. - Стаття.

У статті розкрито зміст універсальних міжнародно-правових стандартів здійснення суверенними державами управління у сфері забезпечення інформаційної безпеки. На основі аналізу документів Організаціі Об’єднаних Націй у сфері прав людини, а також актів $\mathrm{OOH}$ із питань регулювання інформаційних процесів, встановлено, що універсальні стандарти є похідними від загальних принципів здійснення державного управління, які визнано ООН як універсальні (пріоритет дотримання прав людини, демократизм політичної системи, верховенство закону і т.д.).

Визначено, що основними універсальними міжнародно-правовими стандартами державного управління у сфері забезпечення інформаційної безпеки є: гарантування права кожному вільно шукати, одержувати i поширювати інформацію та ідеї будь-якими засобами; вільне висловлення власної думки; забезпечення балансу між правоохоронними інтересами і повагою до основних прав людини; сприяння ефективності кримінальних розслідувань і переслідувань, що стосуються кримінальних правопорушень, пов'язаних із комп'ютерними системами; криміналізація діянь, що пов'язані з посяганням на кіберпростір; сприяння визнанню юридичної сили інформації, яка міститься в електронних повідомленнях, що використовуються в процесі налагодження міжнародної торгівлі; забезпечення гендерної рівності в доступі i використанні інформаційних технологій; гарантування державою можливості недостатньо соціально забезпеченим верствам населення користуватися інформаційними технологіями, налагодження державно-приватного партнерства у фінансуванні розвитку інформаційно-комунікаційної інфраструктури.

Акцентовано на тому, що практичне втілення універсальних стандартів стане потужним чинником збільшення рівня доступності інформаційно-комунікаційних технологій для всіх верств населення держав світу, буде сприяти розвитку інформаційно-комунікаційноі інфраструктури суверенних держав, дасть додатковий імпульс для законодавчої регламентації забезпечення інформаційної безпеки на національному рівні. Зазначено, що міжнародно-правова основа здійснення державного управління у сфері забезпечення інформаційної безпеки потребує вдосконалення в частині розробки i затвердженні окремого акта міжнародного права, який би містив уніфікований перелік рекомендованих стандартів для суверенних держав, які б втілювалися задля забезпечення інформаційної безпеки на національному рівні. Означені питання мають стати пріоритетним напрямом подальших наукових розробок.

Ключові слова: Україна, інформація, державне управління, інформаційна безпека, універсальні міжнародно-правові стандарти, Організація Об'єднаних Націй, права людини.

\section{Summary}

Yakovlev $P$. O. Universal international legal standards of public administration in the field of information security. - Article.

The article describes the content of universal international legal standards for the implementation of sovereign governments in the field of information security. Based on the analysis of United Nations human rights instruments and UN acts on information regulation, it is established that universal standards are derived from the general principles of public administration that are recognized by the UN as universal (human rights priority, democracy political system, the rule of law, etc.).

It is determined that the basic universal international legal standards of public administration in the field of information security are: guaranteeing the right of everyone to freely seek, receive and impart information and ideas by any means; to express freely one's own opinion; ensuring a balance between law enforcement interests and respect for fundamental human rights; promoting the effectiveness of criminal investigations and prosecutions relating to criminal offenses related to computer systems; criminalizing acts related to cyberspace encroachment; promoting the recognition of the legal information contained in electronic communications used in the process of establishing international trade; ensuring gender equality in access to and use of information technologies; guaranteeing the state the opportunity for the underprivileged population to use information technologies, establishing a public-private partnership in financing the development of information and communication infrastructure.

It is emphasized that the practical implementation of universal standards will be a powerful factor in increasing the level of availability of information and communication technologies for all segments of the population of the countries of the world, will contribute to the development of information and communication infrastructure of sovereign states, will give additional impetus to the legislative regulation of information security at the national level. It was noted that the international legal basis for the implementation of public administration in the field of information security requires improvement in the development and approval of a separate act of international law, which would contain a unified list of recommended standards for sovereign states that would be implemented to ensure information security at national level. These issues should be a priority for further scientific development.

Key words: Ukraine, information, public administration, information security, universal international legal standards, United Nations, human rights. 